\title{
TITLE:
}

\section{Localization and Activity of Membrane Dipeptidase in Bovine Ciliary Epithelium(Abstract_要旨 )}

$\operatorname{AUTHOR}(S)$ :

Ikeda, Hiromi

\section{CITATION:}

Ikeda, Hiromi. Localization and Activity of Membrane Dipeptidase in Bovine Ciliary Epithelium. 京都大学, 2003, 博士(医学)

ISSUE DATE:

2003-01-23

URL:

http://hdl.handle.net/2433/149376

RIGHT: 
氏名池望签美

学位(専攻分野) 博士（医学）

学位記番号論医 博第 1801 号

学位授与の日付平 成 15 年 1 月 23 日

学位授与の要件 学 位 規 則第 4 条第 2 項該 当

学位論文題目 Localization and Activity of Membrane Dipeptidase in Bovine Ciliary Epithelium

（ウシ毛様体上皮に扔ける Membrane Dipeptidase の局在と活性に関する研 究)

論文調査委員教授成宮周教授伊藤壽一教授本田孔士

\section{論文 内 容 の 要旨}

Membrane dipeptidase（MDP）は，肺や腎臓などでの研究によって，強い炎症誘因物質である Leukotriene（LT）D4 のペプチド部分を切断することで炎症誘因作用の弱いLTE4へ変換する酵素であることが，明らかにされてきた。また $\mathrm{MDP}$ は，C 末端に D 体の phenylalanine（D-Phe）を有するペプチドを加水分解する $\beta$-lactamase 活性を持った哺乳類で は唯一の酵素である。今回, 我々はウシ眼球内での MDP の存在部位㧍よびその酥素活性を検討し, 毛様体の生理的機能を 明らかにすることを目的として，次の実験を行った。

方法：1）ウシ眼の毛様体を抗原として，単クローン抗体を作製した。この抗体を用いた間接蛍光抗体法により，ウシ眼 内での抗原の存在部位を調べた。

2) Affinity Chromatography 拉よびSDS-PAGEにて抗原を精製し，N末端および内部ペプチドのアミノ酸配列の分析を 行った。3）MDPの $\beta$-lactamase 活性を調べるため, Gly-D-Phe から放出されたD-Phe 蛍光定量法で測定した。また LTD4 から LTE4 への変換を酵素免疫定量法にて測定した。4）次に毛様体に扔ける醳素活性のうち MDP が寄与してい る割合を調べるため，単クローン抗体を結合させたゲルに毛様体のホモジネートに含まれるMDP 結合させ，結合分画と 非結合分画の酵素活性を比較した。

結果：1）作製した単クローン抗体に反応する抗原分子は，ウシ眼球内では毛様体色素上皮および毛様体無色素上皮のみ に局在していた。2）抗原分子は，アミノ酸配列分析によりヒッジのMDP と高い相同性をもっことがわかった。3） $\beta$ lactamase 活性は毛様体のホモジネート中に明らかに認められたが, 神経網膜と網膜色素上皮にはほとんど認められなかっ た。LTD4 から LTE4への変換は，神経網膜に比べて毛様体のホモジネート中で著しく高いことがわかった。4） $\beta$-lactamase 活性はほぼ100\%が単クローン抗体結合分画で認められた。LTD4 から LTE4への変換は，単クローン抗体結合分画 で約 $55 \%$ ，非結合分画で約 $45 \%$ の活性が認められた。

結論 : 我々は, 免疫組織染色と $\beta$-lactamase 活性を測定することにより，毛様体にMDP が存在することを初めて証明し た。また，毛様体は炎症誘因作用が強いLTD4をLTE4へ変換することが可能であり，この変換は少なくとも2 種類の㥢 素で触媒され，その過半はMDPに上って行われていることを明らかにした。今後，毛様体の眼内炎への関わり方を解明す る上で, 今回の MDP の研究結果は大きく寄与するものと思われる。

\section{論 文 審 查の 結 果 の 要 旨}

毛様体は房水を産生し, 眼内の代謝産物を能動的に器官外に運び出している。また毛様体上皮には血液房水関門が存在し, 血液中の物質変動に抗して眼内の環境を安定させる役割を果たしている。このように毛様体は眼内の恒常性を保つ重要な機 能を持つことが知られているが，いまだ解明されていない生理的側面も多い。

本論文では，まずウシ眼の毛様体を抗原として特異な染色パターンを示す単クローン抗体を作製した。抗原蛋白を精製し てアミノ酸配列の分析を行い, 抗原分子が Membrane dipeptidase（MDP）であることを明らかにした。また間接蛍光抗体 
法により眼内ではMDP は毛様体上皮のみに局在し，他の組織には存在しないことを明らかにした。次に毛様体での Leukotriene（LT）D4 から LTE4への変換速度を測定し，その過半はMDP の酵素活性が担っていることを示した。

MDP は，肺や腎臟などで強い炎症誘因物質であるLTD4を炎症誘因作用の弱いLTE4 に変換する酵素であることが明 らかにされている。今まで眼内でのこの酵素の分布・役割についての知見は皆無であったが，本研究は毛様体が炎症反応抑 制という新たな作用を持つ可能性を示した。

以上の研究は，毛様体の機能の解明に貢献し，また眼内炎などの病態の解明に寄与するところが大きい。

したがって，本論文は博士 (医学) の学位論文として価値あるものと認める。

なお，本学位授与申請は，平成14年12月26日実施の論文内容とそれに関連した研究分野並びに学識確認のための試問を受 け，合格と認められたものである。 